\title{
Pengaruh Sistem Akuntansi Pemerintahan, Budaya Organisasi, Kinerja Aparatur Pemerintah Daerah, Peran APIP, Dan Sistem Pengendalian Intern Pemerintah Terhadap Penerapan Good Governance (Studi Empiris Di Kabupaten Kepulauan Talaud)
}

\author{
JEFRI HERBERT MAILOOR ${ }^{1}$, JULLIE J. SONDAKH ${ }^{2}$, HENDRIK GAMALIEL ${ }^{3}$ \\ 1,2,3 Program Studi Magister Akuntansi, Fakultas Ekonomi dan Bisnis Universitas Sam Ratulangi \\ email : jmailoor10@gmail.com ${ }^{1}$, julliesondakh@yahoo.com ${ }^{2}$, hendrik_gamaliel@unsrat.ac.id $^{3}$
}

\begin{abstract}
This study aims to test empirically the effects of government accounting system, organizational culture, performance of regional government officials, the role of government internal auditor, and government internal control system towards the implementation of good governance in Talaud Islands District. This research was conducted at Talaud Islands Regency officials by using purposive sampling method. Data were collected by distributing questionnaires to 145 respondents at 28 SKPD. Data was analysed by using multiple linear regression with SPSS version 23 software. T-test was conducted to test the hypothesis partially. Results of this study show that: (1) The government's accounting system has a positive and significant influence on the implementation of good governance, with t-value of 4.342 and significance value of 0.000; (2) The organizational culture has a negative and insignificant influence on the implementation of good governance, with $t$-value of -1.019 and significance value of 0.310 ; (3) The performance of regional government officials has a positive and significant influence on the implementation of good governance, with t-value of 2.458 and significance value of 0.015 ; (4) The role of APIP has a positive and significant influence on the application of good governance, with t-value of 6.647 and significance value of 0.000; (5) The government's internal control system has a positive and significant influence on the implementation of good governance, with t-value of 2.128 and significance value of 0.035 . The amount of variation of the variables of good governance implementation which can be explained by variables in this research is $84.8 \%$, while the remaining $15.2 \%$ is the contribution of other variables that are excluded in this research model.
\end{abstract}

Keywords: Government Accounting System, Organizational Culture, Performance of Government Officials, The Role of Government Internal Auditor, Government Internal Control System, Good Governance.

\begin{abstract}
Abstrak. Penelitian ini bertujuan untuk menguji secara empiris pengaruh sistem akuntansi pemerintahan, budaya organisasi, kinerja aparatur pemerintah daerah, peran aparat pengawasan intern pemerintah, dan sistem pengendalian intern pemerintah terhadap penerapan good governance di Kabupaten Kepulauan Talaud. Penelitian ini dilakukan pada aparatur Kabupaten Kepulauan Talaud dengan menggunakan metode purposive sampling. Pengumpulan data dilakukan dengan menyebarkan angket kuesioner pada 145 responden di 28 SKPD. Metode analisis data menggunakan regresi linear berganda dengan bantuan SPSS versi 23. Untuk menguji hipotesis secara parsial digunakan Uji-t. Hasil penelitian menunjukkan bahwa: (1) Sistem akuntansi pemerintahan berpengaruh positif dan signifikan terhadap penerapan good governance, dimana nilai $\mathrm{t}=4,342$ dan nilai signifikan 0,000; (2) Budaya organisasi berpengaruh negatif dan tidak signifikan terhadap penerapan good governance, dimana nilai $\mathrm{t}=-1,019$ dan nilai signifikan 0,310; (3) Kinerja aparatur pemerintah daerah berpengaruh positif dan signifikan terhadap penerapan good governance, dimana nilai $\mathrm{t}=2,458$ dan nilai signifikan 0,015; (4) Peran APIP berpengaruh positif dan signifikan terhadap penerapan good governance, dimana nilai $\mathrm{t}=6,647$ dan nilai signifikan 0,000 ; (5) Sistem pengendalian intern pemerintah berpengaruh positif dan signifikan terhadap penerapan good governance, dimana nilai $\mathrm{t}=2,128$ dan nilai signifikan 0,035 . Besarnya variasi dari variabel penerapan good governance yang dapat dijelaskan oleh variabel-variebel penelitian ini adalah sebesar 84,8 \%, sedangkan sisanya sebesar 15,2 \% dijelaskan atau merupakan kontribusi variabel lain tetapi tidak terdapat dalam model penelitian ini.
\end{abstract}

Kata Kunci: Sistem Akuntansi Pemerintahan, Budaya Organisasi, Kinerja Aparatur Pemerintah, Peran Aparat Pengawasan Intern Pemerintah, Sistem Pengendalian Intern Pemerintah, Good Governance.

\section{Pendahuluan}

Desentralisasi pemerintahan dan pelaksanaan kebijakan otonomi daerah merupakan delegasi wewenang dari pemerintah pusat ke daerah. Dengan perubahan sistem pemerintahan ini memberi dampak pada penyelenggaraan pemerintahan juga berdampak pada perubahan sistem keuangan pemerintah daerah. Dalam UU No. 17 Tahun 2003 tentang Keuangan Negara mengatur antara lain pengelolaan keuangan daerah meliputi penyusunan Anggaran Pendapatan dan Belanja Daerah (APBD) 
berbasis kinerja dan laporan keuangan sebagai bentuk pertanggungjawaban yang harus diperiksa oleh Badan Pemeriksa Keuangan Republik Indonesia (BPK-RI). Pemerintah Daerah Kabupaten Kepulauan Talaud dalam rangka penerapan prinsip good governance telah melakukan upaya meningkatkan kinerja, transparansi dan akuntabilitas pengelolaan keuangan daerah. Upaya-upaya yang dilakukan oleh Pemerintah Daerah Kabupaten Kepulauan Talaud tersebut antara lain: pertama, penyampaian laporan pertanggungjawaban keuangan pemerintah daerah berupa Laporan Keuangan Pemerintah Daerah (LKPD) yang memenuhi kriteria relevan, andal, dapat dibandingkan dan dapat dipahami sesuai PP No. 71 Tahun 2010 tentang Standar Akuntansi Pemerintahan. LKPD diaudit oleh BPK-RI sesuai amanat UU No. 15 Tahun 2004 tentang Pemeriksaan Pengelolaan dan Tanggung Jawab Keuangan Negara, BPK-RI melakukan pemeriksaan atas laporan keuangan pemerintah dalam rangka memberikan opini tentang tingkat kewajaran informasi yang disajikan dalam laporan keuangan pemerintah pusat dan daerah. Kedua, Pemerintah Kabupaten Kepulauan Talaud menyampaikan Laporan Akuntabilitas Kinerja Instansi Pemerintah (LAKIP) sebagai bentuk kewajiban memberikan pertanggungjawaban implementasi Perencanaan Strategis (Renstra) atas setiap aktivitas dan kinerja pemerintah daerah kepada pihak yang berkepentingan (stakeholder).

Berdasarkan kajian dan ulasan sebelumnya, penulis menduga faktor-faktor yang mempengaruhi penerapan good governance diantaranya adalah sistem akuntansi pemerintahan, budaya organisasi, kinerja aparatur pemerintah daerah, peran aparat pengawasan intern pemerintah (APIP), dan sistem pengendalian intern pemerintah (SPIP). Keberhasilan penerapan good governance diduga tidak dapat tercapai tanpa dukungan faktor-faktor tersebut. Faktor pertama yang mempengaruhi penerapan good governance adalah sistem akuntansi pemerintahan. Mardiasmo (2009) menyatakan peningkatan perencanaan dan pengendalian terhadap aktivitas pemerintahan dengan cara perbaikan sistem akuntansi sektor publik diharapkan dapat membantu meningkatkan transparansi, efisiensi serta efektivitas pemerintah daerah, terutama dalam memberikan informasi atas aktivitas dan kinerja keuangan pemerintah daerah. Jika sistem akuntansi handal maka untuk mewujudkan good governance bisa dicapai. Faktor kedua yang mempengaruhi penerapan good governance adalah budaya organisasi. Mardiasmo, Barnes dan Sakurai (2008) menyatakan bahwa budaya pemerintahan daerah merupakan variabel rintangan utama dalam pelaksanaan good governance. Budaya organisasi yang diharapkan akan memotivasi aparatur memiliki kinerja pelayanan publik sehingga mendukung penerapan prinsip good governance.

Faktor ketiga yang mempengaruhi good governance adalah kinerja aparatur pemerintah daerah. Fenomena utama yang dihadapi pemerintah daerah saat ini adalah keterbatasan aparatur pemerintah daerah yang berkualitas dalam penyelenggaraan pemerintahan daerah di Indonesia (Enceng dan Purwaningdyah, 2008). Untuk menghasilkan informasi laporan keuangan yang bermanfaat, maka laporan keuangan harus disusun sesuai sistem keuangan daerah dan pegawai pemerintah memiliki kemampuan dibidang pengelolaan keuangan dan sistem akuntansi (Tuasikal, 2009). Faktor keempat yang mempengaruhi good governance adalah aparat pengawasan intern pemerintah. Institusi APIP pada pemerintah provinsi/kabupaten/kota disebut Inspektorat provinsi/kabupaten/kota. Good governance akan tercapai jika lembaga pengawas dan pemeriksa (audit internal) berfungsi secara baik (Mardiasmo, 2002). Faktor kelima yang mempengaruhi good governance adalah sistem pengendalian intern pemerintah. Dalam Peraturan Pemerintah No. 60 Tahun 2008 tentang Sistem Pengendalian Intern Pemerintah dijelaskan tujuan sistem pengendalian intern adalah untuk memberikan keyakinan yang memadai bagi tercapainya efektivitas dan efisiensi pencapaian tujuan penyelenggaraan pemerintahan negara, keandalan pelaporan keuangan, pengamanan aset negara, dan ketaatan terhadap peraturan perundang-undangan.

Berdasarkan uraian latar belakang sebelumnya, maka permasalahan dalam penelitian ini adalah sebagai berikut:

1. Apakah sistem akuntansi pemerintahan berpengaruh terhadap penerapan good governance?

2. Apakah budaya organisasi berpengaruh terhadap penerapan good governance?

3. Apakah kinerja aparatur pemerintah daerah berpengaruh terhadap penerapan good governance?

4. Apakah peran APIP berpengaruh terhadap penerapan good governance?

5. Apakah sistem pengendalian intern pemerintah berpengaruh terhadap penerapan good governance?

Tujuan yang hendak dicapai dalam penelitian ini adalah untuk menguji secara empiris semua rumusan masalah yang ada. Manfaat penelitian ini bagi pemerintah daerah, diharapkan sebagai masukan untuk semua pihak yang memerlukan agar lebih memperhatikan penerapan good governance dalam hal pengelolaan keuangan daerah; bagi praktisi, diharapkan dapat memberikan sumbangan 
pemikiran dalam mengambil kebijakan mengenai implementasi sistem akuntansi pemerintahan, budaya organisasi, kinerja aparatur pemerintah daerah, peran APIP, dan sistem pengendalian intern pemerintah agar good governance bisa tercapai; bagi akademisi, untuk memperkaya khasanah penelitian bagi perkembangan ilmu pengetahuan di dunia pendidikan/akademis khususnya terkait dengan topik penelitian ini, serta dapat menjadi bahan referensi terhadap masalah dan jenis penelitian yang sama.

\section{Gambar 1 Kerangka Konseptual Penelitian}

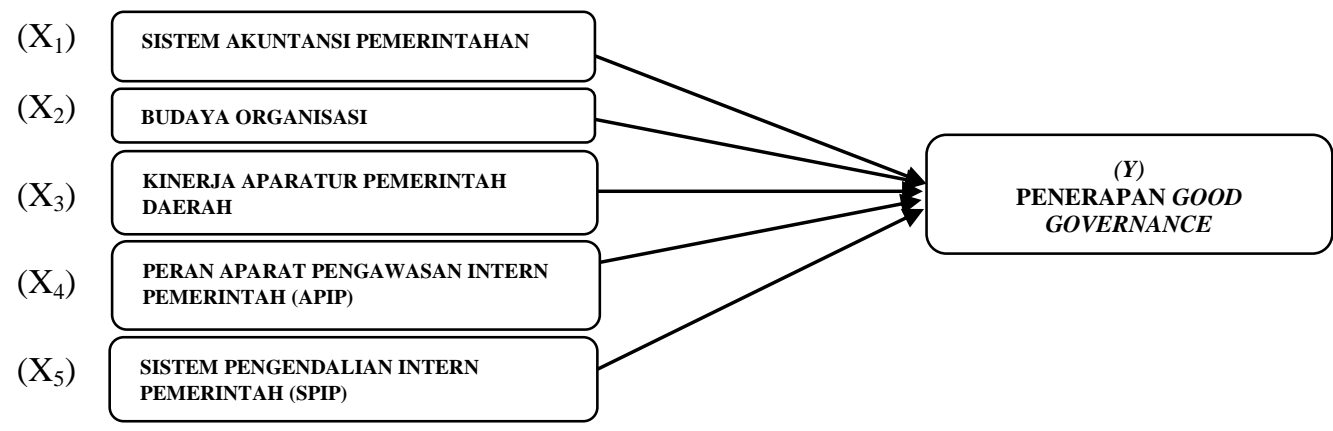

Berdasarkan landasan teori dan hasil-hasil penelitian terdahulu, maka hipotesa dalam penelitian ini dirumuskan menjadi 5 (lima) hipotesa:

1. Pengaruh Sistem Akuntansi Pemerintahan terhadap Penerapan Good Governance.

Menurut Pazri (2016) pengelolaan keuangan daerah yang baik dengan menggunakan prinsip good governance akan membuat setiap pemasukan dan pengeluaran anggaran bisa dipertanggungjawabkan secara finansial sehingga pengelolaan keuangan yang baik akan menciptakan akuntabilitas publik. Mardiasmo (2004) menyatakan bahwa untuk dapat menghasilkan laporan keuangan yang relevan, handal, dan dapat dipercaya, pemerintah daerah harus memiliki sistem akuntansi yang handal. Studi empiris yang dilakukan oleh Yusniyar, Darwis dan Abdullah (2016) menunjukkan hasil bahwa sistem akuntansi pemerintahan berpengaruh terhadap good governance. Berdasarkan atas dasar dukungan teoritis dan bukti empiris yang telah dipaparkan sebelumnya, maka hipotesis:

$\mathrm{H}_{1}$ : Sistem akuntansi pemerintahan berpengaruh positif dan signifikan terhadap penerapan good governance.

\section{Pengaruh Budaya Organisasi terhadap Penerapan Good Governance.}

Penerapan budaya yang kuat dalam suatu organisasi akan meningkatkan keefektifan organisasi tersebut. Seperti yang diungkapkan oleh Stephen Robbins (1994) dalam Fahmi (2014), budaya yang kuat dicirikan oleh nilai inti dari organisasi yang dianut dengan kuat, diatur dengan baik, dan dirasakan bersama-sama secara luas. Budaya organisasi yang kuat dan luas akan meningkatkan keberhasilan kinerja suatu organisasi pemerintah. Apabila budaya organisasi suatu instansi pemerintah kuat pasti membuat pelayanan terhadap masyarakat akan tercapai. Hasil penelitian Hanpuwadal dan Ussahawanitchakit (2010) menyatakan budaya organisasi sebagai aspek yang penting dari kegiatan organisasi. Berdasarkan atas dasar dukungan teoritis dan bukti empiris yang telah dipaparkan sebelumnya, maka hipotesis:

\section{$\mathrm{H}_{2}$ : Budaya organisasi berpengaruh positif dan signifikan terhadap penerapan good governance.}

\section{Pengaruh Kinerja Aparatur Pemerintah Daerah terhadap Penerapan Good Governance.}

Bastian (2001) dalam Verasvera (2016) mendefinisikan kinerja adalah gambaran mengenai tingkat pencapaian pelaksanaan suatu kegiatan atau program atau kebijakan dalam mewujudkan sasaran, tujuan, misi, dan visi organisasi yang tertuang dalam perumusan skema strategis (strategic planning) suatu organisasi. Kinerja aparatur merupakan ekspresi keberhasilan tercapainya tujuan organisasi yang telah ditetapkan, yang menunjukkan kualitas dan kuantitas hasil kerja yang dicapai oleh seorang aparatur dalam melaksanakan tugasnya dan dipengaruhi oleh kemampuan dan sikap yang dimilikinya. Isu sentral dari pelaksanaan otonomi daerah adalah terselenggaranya pemerintahan yang good governance. Dengan menerapkan good governance diperlukan kinerja aparatur pemerintah yang baik, kondusif, responsif, dan adaptif sehingga akan menghasilkan karakteristik good governance. Studi empiris tentang kinerja aparatur dilakukan oleh Ruspina (2013) dimana hasil pengujian menunjukkan kinerja aparatur pemerintah daerah berpengaruh signifikan positif terhadap good 
governance. Berdasarkan atas dasar dukungan teori dan bukti empiris yang telah dipaparkan sebelumnya, maka hipotesis:

\section{$\mathrm{H}_{3}$ : Kinerja aparatur pemerintah daerah berpengaruh positif dan signifikan terhadap penerapan good governance.}

\section{Pengaruh Peran APIP terhadap Penerapan Good Governance.}

Good governance akan tercapai jika lembaga pengawas dan pemeriksa (audit internal) berfungsi secara baik (Mardiasmo, 2002). Auditor Internal adalah audit yang dilakukan oleh unit pemeriksaan yang merupakan bagian dari organisasi yang diawasi. Wakhyudi (2010) menyatakan peran APIP sebagai auditor intern pemerintah diwujudkan dalam bentuk: mendorong terwujudnya good governance dan clean government; menumbuhkembangkan sinergi pengawasan; mendukung upaya pemberantasan KKN; mengoptimalkan peningkatan penerimaan negara. Kajian empiris oleh Armana (2016) Satuan Pengawasan Internal (SPI) berpengaruh terhadap penerapan prinsip-prinsip Good Corporate Governance (GCG). Dengan melaksanakan peran sebagai aparat pengawasan intern yang efektif maka akan mewujudkan peningkatan good governance. Berdasarkan atas dasar dukungan teori dan bukti empiris yang telah dipaparkan sebelumnya, maka hipotesis:

\section{$\mathrm{H}_{4}$ : Peran APIP berpengaruh positif dan signifikan terhadap penerapan good governance.}

\section{Pengaruh Sistem Pengendalian Intern Pemerintah terhadap Penerapan Good Governance.}

Dalam Peraturan Pemerintah No. 60 Tahun 2008 menyatakan Sistem Pengendalian Intern Pemerintah (SPIP) bertujuan untuk memberikan keyakinan memadai atas tercapainya tujuan organisasi melalui kegiatan yang efektif dan efisien, keandalan laporan keuangan, pengamanan aset negara dan ketaatan terhadap peraturan perundang-undangan. Sistem pengendalian intern pemerintah meliputi lima elemen untuk memberi jaminan bahwa sasaran pengendalian internal telah dipenuhi. Dengan diterapkannya pengendalian intern yang efektif, maka informasi keuangan yang dihasilkan pemerintah akan handal, relevan dan sesuai aturan yang berlaku sebagai wujud komitmen pemerintah membangun good governance. Kajian empiris sistem pengendalian intern berpengaruh terhadap penerapan good governance (Sari, 2013, Lestari 2008 dan Armana, 2016). Berdasarkan atas dasar dukungan teori dan bukti empiris yang telah dipaparkan sebelumnya, maka hipotesis:

\section{$H_{5}$ : Sistem pengendalian intern pemerintah berpengaruh positif dan signifikan terhadap} penerapan good governance.

\section{Metode Penelitian}

Jenis penelitian ini menganalisis faktor-faktor yang mempengaruhi penerapan good governance di Kabupaten Kepulauan Talaud dengan menggunakan data kuantitatif. Sumber data yang digunakan dalam penelitian ini data primer, yaitu data yang diperoleh menggunakan instrumen daftar pertanyaan (kuesioner). Adapun populasi dari penelitian ini adalah seluruh Aparatur Sipil Negara (ASN) yang terlibat dalam penilaian dan penentuan kebijakan di pemerintahan, pengelolaan keuangan dan pengawasan. Populasi yang digunakan dalam penelitian ini sebanyak 226 pegawai eselon II, III dan IV. Sampel yang diambil sejumlah 145 aparatur pada 28 SKPD di Pemerintah Kabupaten Kepulauan Talaud yang terdiri dari Inspektorat, Sekretariat Daerah, Sekretariat Dewan, Badan dan Dinas. Pemilihan lokasi penelitian didasarkan pada pertimbangan bahwa penerapan good governance terjadi di SKPD.

\section{Definisi Operasional dan Pengukuran Variabel}

\section{Sistem Akuntansi Pemerintahan $\left(\mathbf{X}_{1}\right)$}

Peran dan keberadaan sistem akuntansi pemerintah daerah dalam menunjang terciptanya akuntabilitas keuangan. Indikator sistem akuntansi meliputi prosedur sistem akuntansi SKPD, penyelenggara, dan pemberi informasi (Permendagri No. 64 Tahun 2013). Kuesioner yang digunakan merupakan kuesioner yang telah digunakan dalam penelitian Yusniyar et al. (2016) dan dikembangkan menyesuaikan kebutuhan penelitian ini.

\section{Budaya Organisasi $\left(X_{2}\right)$}

Budaya organisasi adalah nilai-nilai dan keyakinan yang tercipta, diterapkan dan dikembangkan bersama sebagai acuan perilaku pegawai dalam organisasi. Indikator budaya meliputi inovasi, perhatian pada hal-hal rinci, orientasi pada individu, orientasi pada hasil serta orientasi bersama (Robbins dan Judge, 2016). Kuesioner yang digunakan merupakan kuesioner yang telah digunakan dalam penelitian Wiratno, Pratiwi, dan Nurkhikmah (2013) dan dikembangkan menyesuaikan kebutuhan penelitian ini. 


\section{Kinerja Aparatur Pemerintahan $\left(\mathbf{X}_{3}\right)$}

Kinerja aparatur adalah ukuran pelaksanaan pekerjaan aparatur dengan baik dan menunjukkan hasil. Indikator kinerja berdasarkan kualitas kerja, kuantitas kerja dan ketangguhan (Flippo, 2000, Mathis dan Jackson, 2006). Kuesioner yang digunakan merupakan kuesioner yang telah digunakan dalam penelitian Lenda (2013) dan dikembangkan menyesuaikan kebutuhan penelitian ini.

4. Peran APIP $\left(\mathbf{X}_{4}\right)$,

Peran APIP yang dimaksud adalah peran institusi Inspektorat daerah melaksanakan fungsi pengawasan. Indikator peran APIP melalui kegiatan audit, evaluasi, reviu, dan pemantauan dalam rangka memberikan keyakinan yang memadai atas aktivitas pemerintah daerah (Peraturan Pemerintah No. 60 Tahun 2008). Kuesioner yang digunakan merupakan kuesioner yang telah digunakan dalam penelitian Dodopo, Sondakh dan Tinangon (2017) dan dikembangkan menyesuaikan kebutuhan penelitian ini.

\section{Sistem Pengendalian Intern Pemerintah $\left(\mathbf{X}_{5}\right)$}

Sistem Pengendalian Intern Pemerintah adalah proses pengendalian yang melekat pada kegiatan yang dilakukan pimpinan dan pegawai untuk memperoleh keyakinan memadai terhadap pencapaian tujuan organisasi. Indikator sistem pengendalian intern pemerintah yaitu lingkungan pengendalian, penilaian risiko, kegiatan pengendalian, informasi dan komunikasi serta pemantauan (Peraturan Pemerintah No. 60 Tahun 2008). Kuesioner yang digunakan merupakan kuesioner yang telah digunakan dalam penelitian (Sari, 2013, Wiratno et al., 2013) dan dikembangkan menyesuaikan kebutuhan penelitian ini.

\section{Penerapan good governance (Y).}

Good governance sebagai suatu penyelenggaraan manajemen pemerintahan yang baik dan bertanggungjawab serta efisien dan efektif untuk tujuan organisasi dengan menjaga sinergi antara pemerintah, masyarakat dan swasta. Indikator good governance yaitu transparansi, partisipasi dan akuntabilitas (LAN dan BPKP, 2000, Krina P., 2003, Osborne dan Geabler, 1992). Kuesioner yang digunakan dalam penelitian ini merupakan kuesioner yang telah digunakan Zeyn (2011) dan dikembangkan menyesuaikan kebutuhan penelitian ini.

\section{Hasil dan Pembahasan}

Data dalam penelitian ini dikumpulkan dengan cara menyebarkan kuesioner langsung kepada objek penelitian. Dari 145 kuesioner yang disebarkan, kuesioner yang kembali sebanyak 135 kuesioner dan 10 kuesioner tidak dikembalikan.

\section{Uji Validitas Data}

Pengujian validitas dilakukan untuk menguji apakah pernyataan dalam kuesioner telah sesuai mengukur konsep yang dimaksud. Pengujian validitas dalam penelitian ini menggunakan Pearson Correlation yaitu dengan cara menghitung korelasi antara skor masing-masing butir pernyataan dengan skor total. Hasil uji validitas atas variabel sistem akuntansi pemerintahan $\left(\mathrm{X}_{1}\right)$, budaya organisasi $\left(\mathrm{X}_{2}\right)$, kinerja aparatur pemerintah daerah $\left(\mathrm{X}_{3}\right)$, peran $\operatorname{APIP}\left(\mathrm{X}_{4}\right)$, sistem pengendalian intern pemerintah $\left(\mathrm{X}_{5}\right)$ dan penerapan good governance $(\mathrm{Y})$ menunjukkan bahwa nilai $\mathrm{r}^{-}$hitung seluruh butir pernyataan variabel penelitian lebih besar dari $\mathrm{r}_{\text {tabel }}, \alpha=0,1690$. Selain itu semua item pernyataan untuk variabel penelitian memiliki kriteria valid dengan nilai signifikansi $<0,05$. Dengan demikian, hasil uji validitas menyatakan bahwa semua butir pernyataan dari instrumen yang digunakan untuk mengukur variabel-variabel yang dianalisis di dalam penelitian ini adalah valid.

\section{Uji Reliabilitas}

Suatu kuesioner dikatakan reliabel atau handal jika jawaban seseorang terhadap pernyataan adalah konsisten atau stabil dari waktu ke waktu. Hasil uji reliabilitas menunjukkan nilai Cronbach's Alpha untuk variabel sistem akuntansi pemerintahan sebesar 0,794; budaya organisasi sebesar 0,750; kinerja aparatur pemerintah daerah sebesar 0,765; peran APIP sebesar 0,858; sistem pengendalian intern pemerintah sebesar 0,900 dan penerapan good governance sebesar 0,813. Dengan demikian dapat disimpulkan bahwa pernyataan dalam kuesioner ini reliable karena memiliki nilai Cronbach's Alpha > 0,60. Hal ini menunjukkan bahwa apabila pernyataan diajukan kembali akan diperoleh jawaban yang relatif sama dengan jawaban sebelumnya.

\section{Uji Asumsi Klasik}

\section{UJi Normalitas Data}

Uji normalitas dilakukan untuk mengetahui data berdistribusi normal. Uji normalitas dalam penelitian ini dengan menggunakan analisis uji Kolmogorov-Smirnov (Uji K-S) dan grafik P-Plot 
SPSS. Melalui grafik P-Plot dapat dinilai dari titik-titik penyebaran disekitar garis diagonal apakah searah dan mengikuti garis diagonal, sedangkan pada Uji K-S akan dilihat nilai signifikansinya apabila lebih besar dari 0,05 maka menunjukkan sebaran data tidak menyimpang dari kurva normalnya atau dengan kata lain data tersebut berdistribusi normal. Sebaliknya, nilai signifikansi hasil Uji K-S yang lebih kecil dari 0,05 menunjukkan bahwa sebaran data tidak normal.

\section{Gambar 2 Normal P-Plot}

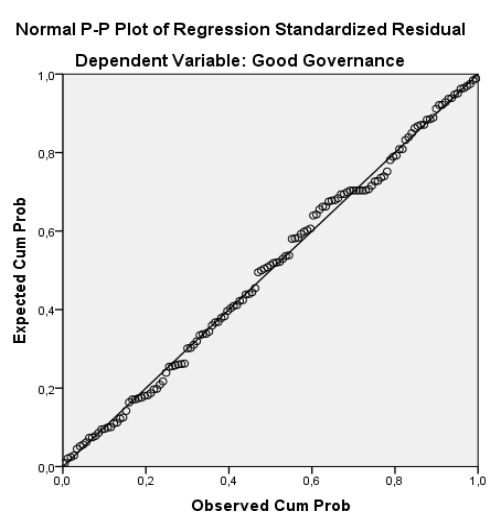

Pada gambar 2 terlihat bahwa titik data menyebar di sekitar garis diagonal dan penyebaran titiktitik data searah mengikuti garis diagonal. Jadi dapat disimpulkan bahwa data terdistribusi dengan normal, sehingga model regresi memenuhi asumsi normalitas.

Tabel 1 Hasil Uji Normalitas

\begin{tabular}{|l|c|}
\hline & Unstandardized Rersidual \\
\hline $\mathrm{N}$ & 135 \\
\hline Kolmogorov-Smirnov & 0,430 \\
\hline Asymp. Sig. (2-tailed) & 0,200 \\
\hline Sumber: Hasil olahan SPSS 2017
\end{tabular}

Berdasarkan Tabel 1 dapat dilihat bahwa hasil uji Kolmogorov-Smirnov nilai koefisien sebesar 0,430 dengan signifikansi 0,200 . Nilai signifikansi $0,200>$ dari alpha $(\alpha=0,05)$ sehingga dapat disimpulkan bahwa model uji telah memenuhi asumsi normalitas.

\section{Uji Multikolinieritas}

Pengujian multikolinieritas dilakukan untuk melihat apakah pada model regresi ditemukan adanya korelasi antara variabel independen. Cara mendeteksinya adalah dengan melihat nilai tolerance dan nilai Variance Inflation Factor (VIF). Jika nilai VIF $<10$ dan tolerance $>0,1$ maka variabel independen terbebas dari persoalan multikolinieritas. Regresi yang baik tidak terdapat korelasi antar variabel independen.

Tabel 2 Hasil Uji Multikolinieritas

\begin{tabular}{|l|c|c|}
\hline \multirow{2}{*}{ Model } & \multicolumn{2}{c|}{ Collinearity Statistics } \\
\cline { 2 - 3 } & Tolerance & VIF \\
\hline Sistem Akuntansi Pemerintahan & 0,316 & 3,165 \\
\hline Budaya Organisasi & 0,397 & 2,520 \\
\hline Kinerja Aparatur Pemerintah Daerah & 0,295 & 3,391 \\
\hline Peran APIP & 0,207 & 4,832 \\
\hline Sistem Pengendalian Intern Pemerintah & 0,274 & 3,654 \\
\hline
\end{tabular}

Sumber: Hasil olahan SPSS 2017

Dari hasil perhitungan di dalam Tabel 2 menunjukkan bahwa semua nilai tolerance $>0,1$ dan nilai VIF < 10. Hal ini menunjukkan bahwa semua variabel independen terbebas dari multikolinieritas.

\section{Uji Heteroskedastisitas}

Uji heterokedastisitas dilakukan untuk mengetahui apakah dalam model regresi terjadi ketidaksamaan varians dari residual suatu pengamatan ke pengamatan lain. Pengujian heterokedastisitas dalam penelitian ini menggunakan Uji Park Glejser. Nilai signifikansi yang lebih besar dari 0,05 berarti bahwa tidak terdapat permasalahan heterokedastisitas. Sebaliknya, jika nilai signifikansi $<0,05$ berarti terdapat permasalahan heterokedastisitas. Hasil pengujian ditunjukkan pada Tabel 3 berikut ini. 
Tabel 3 Hasil Uji Heterokedastisitas dengan Park Glejser

\begin{tabular}{|c|c|c|c|c|c|c|}
\hline & \multirow{2}{*}{ Model } & \multicolumn{2}{|c|}{ Unstandardized Coefficients } & \multirow{2}{*}{$\frac{\text { Standardized Coefficients }}{\text { Beta }}$} & \multirow{2}{*}{$t$} & \multirow{2}{*}{ Sig. } \\
\hline & & $\boldsymbol{B}$ & Std. Error & & & \\
\hline \multirow[t]{6}{*}{1} & (Constant) & $-1,371$ & ,991 & & $-1,384$ &, 169 \\
\hline & $\mathrm{X}_{1}$ & ,038 & ,038 & , 153 & 1,011 & ,314 \\
\hline & $\mathrm{X}_{2}$ &,- 043 &, 051 &,- 114 &,- 840 & ,403 \\
\hline & $\mathrm{X}_{3}$ &, 070 & 057 & ,193 & 1,228 &, 222 \\
\hline & $\mathrm{X}_{4}$ &, 011 &, 043 &, 048 & ,258 &, 797 \\
\hline & $\mathrm{X}_{5}$ &,- 007 & ,026 &,- 044 &,- 269 &, 789 \\
\hline
\end{tabular}

Hasil uji heteroskedastisitas di dalam Tabel 3 menunjukkan bahwa semua nilai signifikansi setiap variabel independen $>0,05$. Hal ini berarti bahwa data di dalam penelitian tidak memiliki permasalahan heterokedastisitas.

\section{Uji Hipotesis Penelitian}

Hasil pengujian asumsi klasik menunjukkan bahwa model regresi yang dipakai telah memenuhi asumsi klasik sehingga dapat dilanjutkan dengan analisis regresi berganda. Model regresi berganda dalam penelitian ini adalah untuk menguji pengaruh sistem akuntansi pemerintahan $\left(\mathrm{X}_{1}\right)$, budaya organisasi $\left(\mathrm{X}_{2}\right)$, kinerja aparatur pemerintah daerah $\left(\mathrm{X}_{3}\right)$, peran APIP $\left(\mathrm{X}_{4}\right)$, dan sistem pengendalian intern pemerintah $\left(\mathrm{X}_{5}\right)$, terhadap penerapan good governance $(\mathrm{Y})$. Analisis regresi berganda di dalam penelitian ini menampilkan beberapa hasil pengujian yaitu: uji $t$, serta uji koefisien korelasi $(\mathrm{R})$ dan determinasi $\left(\mathrm{R}^{2}\right)$. Penjelasan atas hasil pengujian hipotesis dapat dilihat berikut ini.

\section{Pengujian Hipotesis Dengan Uji t}

Pengujian hipotesis dengan uji t dilakukan untuk mengetahui besarnya pengaruh masing-masing (parsial) variabel independen secara individual terhadap variabel dependen. Dalam konteks penelitian ini, hasil uji t bertujuan untuk menunjukkan pengaruh sistem akuntansi pemerintahan, budaya organisasi, kinerja aparatur pemerintah daerah, peran APIP, dan sistem pengendalian intern pemerintah secara parsial terhadap penerapan good governance. Hasil uji t menjadi dasar untuk pengujian beberapa hipotesis penelitian ini.

Tabel 4 Hasil Uji t

Coefficients $^{\mathrm{a}}$

\begin{tabular}{|c|c|c|c|c|c|c|}
\hline & \multirow[b]{2}{*}{ Model } & \multicolumn{2}{|c|}{ Unstandardized Coefficients } & \multirow{2}{*}{$\begin{array}{c}\begin{array}{c}\text { Standardized } \\
\text { Coefficients }\end{array} \\
\text { Beta }\end{array}$} & \multirow[t]{2}{*}{$t$} & \multirow[t]{2}{*}{ Sig. } \\
\hline & & B` & Std. Error & & & \\
\hline \multirow[t]{6}{*}{1} & (Constant) & $-2,507$ & 1,781 & & $-1,408$ &, 162 \\
\hline & SAP & 296 & `,068 & ,261 & 4,342 & ,000 \\
\hline & $\mathrm{BO}$ &,- 094 & 092 &,- 055 & $-1,019$ & ,310 \\
\hline & KAPD & ,251 & ,102 & ,153 & 2,458 &, 015 \\
\hline & PAPIP &, 515 &, 077 & 493 & 6,647 & 000 \\
\hline & SPIP & ,099 & ,047 & 137 & 2,128 & ,035 \\
\hline
\end{tabular}

Berdasarkan Tabel 4, diperoleh persamaan regresi sebagai berikut:

$$
\begin{aligned}
& Y=\alpha+\beta_{1} X_{1}+\beta_{2} X_{2}+\beta_{3} X_{3}+\beta_{4} X_{4}+\beta_{5} X_{5}+e \\
& Y=-2,507+0,296 X_{1}-0,94 X_{2}+0,251 X_{3}+0,515 X_{4}+0,99 X_{5}+e
\end{aligned}
$$

\section{Uji Koefisien Korelasi (R) dan Koefisien Determinasi (Adjusted $\mathbf{R}^{2}$ )}

Uji koefisien korelasi (R) digunakan untuk mengetahui hubungan antara dua atau lebih variabel independen $(\mathrm{X})$ terhadap variabel dependen $(\mathrm{Y})$ secara serentak. Sedangkan uji koefisien determinasi $\left(\mathrm{R}^{2}\right)$ dalam regresi linear berganda digunakan untuk mengetahui persentase kontribusi pengaruh variabel independen secara serentak terhadap variabel dependen (Y). Koefisien ini menunjukkan seberapa besar persentase variasi variabel independen yang digunakan dalam model mampu menjelaskan variasi variabel dependen. Tabel berikut ini merupakan hasil uji koefisien korelasi dan determinasi atas penelitian yang dilakukan.

\begin{tabular}{|c|c|c|c|c|}
\hline Model & $\boldsymbol{R}$ & R Square & Adjusted R Square & Std. Error of the Estimate \\
\hline 1 & $924^{\mathrm{a}}$ & 853 & 848 & 1,369 \\
\hline
\end{tabular}

Tabel 5 Koefisien korelasi 
Pedoman memberikan interpretasi koefisien korelasi menurut Sugiyono (2014) yaitu:

$$
\begin{aligned}
& 0,00-0,199=\text { sangat rendah } \\
& 0,20-0,399=\text { rendah } \\
& 0,40-0,599=\text { sedang } \\
& 0,60-0,799=\text { kuat } \\
& 0,80-1,000=\text { sangat kuat }
\end{aligned}
$$

Berdasarkan Tabel 5, tampilan output SPPS nilai koefisien korelasi (R) sebesar 0,924 menunjukkan bahwa hubungan (korelasi) antara variabel independen dengan variabel dependen merupakan hubungan yang sangat kuat. Artinya sistem akuntansi pemerintahan, budaya organisasi, kinerja aparatur pemerintah daerah, peran APIP dan sistem pengendalian intern pemerintah terhadap penerapan good governance mempunyai hubungan yang sangat kuat.

Untuk regresi dengan lebih dari dua variabel bebas digunakan adjusted $R^{2}$ sebagai koefisien determinasi. Jika nilai adjusted $R^{2}$ sama dengan 0 , maka variasi variabel independen yang digunakan dalam model tidak menjelaskan sedikitpun variasi variabel dependen. Sebaliknya adjusted $R^{2}$ sama dengan 1, maka variasi variabel independen yang digunakan dalam model menjelaskan $100 \%$ variasi variabel dependen. Berdasarkan Tabel 5, nilai adjusted $\mathrm{R}^{2}$ adalah 0,848 yang menunjukkan bahwa variabel bebas yaitu sistem akuntansi pemerintahan, budaya organisasi, kinerja aparatur pemerintah daerah, peran APIP dan sistem pengendalian intern pemerintah mampu menjelaskan perubahan sebesar $84,8 \%$ atas variabel penerapan good governance. Sedangkan sebesar $15,2 \%$ perubahan diterangkan oleh variabel lain yang tidak dimasukkan dalam model penelitian ini.

\section{Pembahasan}

\section{Pengaruh Sistem Akuntansi Pemerintahan terhadap Penerapan Good Governance}

Berdasarkan Tabel 4, nilai signifikansi variabel sistem akuntansi pemerintahan adalah 0,000 lebih kecil dari nilai $\alpha=5 \%$ dan $\mathrm{t}_{- \text {hitung }}=4,342>\mathrm{t}_{\text {tabel }}=1,978$. Hasil ini menunjukkan bahwa variabel sistem akuntansi pemerintahan berpengaruh secara positif dan signifikan secara statistik terhadap variabel penerapan good governance pada tingkat keyakinan 95\%. Dengan demikian, hasil penelitian ini menunjukkan bahwa jika sistem dan prosedur yang digunakan sesuai dengan SAP, serta informasi laporan keuangan dilakukan secara konsisten dan periodik serta didukung dengan sumber daya manusia yang berkompeten dan mampu menggunakan aplikasi SIMDA maka akan terwujud sistem akuntansi pemerintahan yang baik. Sehingga dengan adanya sistem akuntansi pemerintahan, pemerintah daerah mampu menerapkan good governance di Kabupaten Kepulauan Talaud. Hal ini selaras dengan hipotesis yang dinyatakan dalam penelitian ini. Melalui teori stewardship dapat menjelaskan eksistensi pemerintah daerah sebagai suatu lembaga yang dapat dipercaya untuk bertindak sesuai dengan kepentingan publik dengan membuat pertanggungjawaban laporan keuangan, sehingga tujuan ekonomi, pelayanan publik maupun kesejahteraan masyarakat dapat tercapai secara maksimal sesuai prinsip good governance. Dengan demikian penelitian ini mendukung penelitian yang dilakukan oleh Manossoh (2015) serta Yusniyar et al. (2016) bahwa terdapat hubungan antara sistem akuntansi pemerintahan dengan penerapan good governance.

\section{Pengaruh Budaya Organisasi Terhadap Penerapan Good Governance}

Berdasarkan Tabel 4, nilai signifikansi variabel budaya organisasi adalah 0,310 lebih besar dari nilai $\alpha=5 \%$ dan $\mathrm{t}_{\text {-hitung }}=-1,019<\mathrm{t}_{\text {tabel }}=1,978$. Hasil ini menunjukkan bahwa variabel budaya organisasi tidak berpengaruh signifikan secara statistik terhadap penerapan good governance. Hasil ini tidak menunjukkan bahwa aparat pemerintah yang mematuhi budaya organisasi akan meningkatkan penerapan good governance. Dengan demikian, hasil tersebut tidak selaras dengan hipotesis yang dinyatakan oleh penelitian ini. Penelitian ini berpendapat bahwa diperolehnya hasil yang berlawanan dengan hipotesis dapat dijelaskan melalui beberapa fenomena. Fenomena tersebut terkait dengan karakteristik budaya aparatur pemerintahan yang disebabkan karena latar belakang umur, pendidikan, masa kerja, pengalaman kerja dan posisi jabatan yang berbeda dari setiap responden, sehingga persepsi budaya yang muncul adalah budaya individu pribadi dan tidak muncul budaya organisasi yang kuat dan dominan. Jermier, Slocum, Fry, dan Gaines (1991) menyatakan dalam organisasi yang besar memiliki budaya yang dominan tetapi juga memiliki subkultur yang banyak. Menurut Robbins dan Judge (2016) bahwa yang diharapkan dari tiap pegawai dengan latar belakang (subkultur) yang berbeda untuk menggambarkan budayanya dalam istilah yang sama sebagai budaya dominan. Seharusnya budaya yang dominan mengekspresikan nilai-nilai baik yang ada pada mayoritas anggotanya sedangkan subkultur cenderung berkembang untuk mencerminkan permasalahan yang umum atau pengalaman pegawai dalam organisasi yang sama. 
Hasil penelitian ini tidak mengkonfirmasi asumsi filosofi teori stewardship dimana steward merasa kepentingan bersama dan berperilaku sesuai dengan perilaku pemilik merupakan pertimbangan yang rasional karena steward lebih melihat pada usaha untuk mencapai tujuan organisasi. Untuk mencapai tujuan organisasi maka pegawai harus memiliki budaya yang kuat dan sehat tanpa mementingkan kepentingan individu masing-masing. Jika pegawai tidak memiliki budaya pelayanan maka pelayanan publik oleh pemerintah tidak akan berjalan sesuai dengan prinsip-prinsip good governance. Budaya organisasi adalah suatu sistem yang tidak bisa dipisahkan dari perilaku seseorang melaksanakan perannya dalam suatu kelompok atau organisasi. Jika seseorang tidak bisa melaksanakan tugas dan pekerjaannya dengan menunjukkan kinerja sesuai dengan yang diharapkan untuk mencapai tujuan organisasi maka perannya tidak terlaksana. Hasil penelitian ini menunjukkan bahwa budaya organisasi tidak memberikan kontribusi cukup yang diharapkan dalam meningkatkan efektivitas penerapan good governance. Hasil penelitian ini tidak mendukung penelitian sebelumnya yang dilakukan oleh Sari (2012). Hasil penelitiannya menunjukkan bahwa budaya organisasi berpengaruh signifikan terhadap good governance.

\section{Pengaruh Kinerja Aparatur Pemerintah Daerah Terhadap Penerapan Good Governance}

Berdasarkan Tabel 4, nilai signifikansi variabel kinerja aparatur pemerintah daerah adalah 0,015 lebih kecil dari nilai $\alpha=5 \%$ dan $\mathrm{t}_{\text {-hitung }}=2,458>\mathrm{t}_{\text {-tabel }}=1,978$. Hasil ini menunjukkan bahwa variabel sistem kinerja aparatur pemerintah daerah berpengaruh secara positif dan signifikan secara statistik terhadap variabel penerapan good governance pada tingkat keyakinan 95\%. Dengan demikian, hasil penelitian ini menunjukkan bahwa jika aparatur sipil negara mampu menyelesaikan pekerjaan tepat waktu dengan hasil kerja yang rapih, minim kesalahan sesuai dengan sasaran kerja yang telah dibuat maka akan menghasilkan birokrasi yang handal dan profesional efisien, produktif serta memberikan pelayanan prima kepada masyarakat. Sehingga kinerja aparatur mendukung penerapan good governance di Kabupaten Kepulauan Talaud. Hal ini selaras dengan hipotesis yang dinyatakan dalam penelitian ini. Dalam penerapan good governance, aparatur pemerintah daerah diharapkan memberikan pelayanan prima. Dengan adanya kinerja aparatur yang baik penerapan prinsip-prinsip good governance dapat dilakukan sebagai salah satu bentuk dukungan dalam pembangunan kualitas sumber daya manusia. Hasil penelitian ini mendukung penelitian sebelumnya yang dilakukan oleh Ruspina (2013). Hasil penelitiannya menunjukkan kinerja aparatur pemerintah daerah berpengaruh signifikan positif terhadap penerapan good governance.

\section{Pengaruh Peran APIP Terhadap Penerapan Good Governance}

Berdasarkan Tabel 4, nilai signifikansi variabel peran APIP adalah 0,000 lebih kecil dari nilai $\alpha$ $=5 \%$ dan $\mathrm{t}_{\text {-hitung }}=6,647>\mathrm{t}_{\text {-tabel }}=1,978$. Hasil ini menunjukkan bahwa variabel peran APIP berpengaruh secara positif dan signifikan secara statistik terhadap variabel penerapan good governance pada tingkat keyakinan 95\%. Dengan demikian, hasil penelitian ini bahwa jika Inspektorat daerah melaksanakan fungsi dengan melakukan pengawasan melalui audit, reviu, evaluasi dan pemantauan dengan efektif serta menyampaikan laporan pengawasan tepat waktu maka akan mewujudkan tata kelola yang baik serta pengendalian dan pengelolaan risiko yang efektif. Sehingga Inspektorat daerah memiliki peran yang besar dalam upaya pencapaian good governance pada SKPD di Kabupaten Kepulauan Talaud. Hal ini selaras dengan hipotesis yang dinyatakan dalam penelitian ini. Paradigma baru Inspektorat berkembang sebagai consultant dan quality assurer turut bertanggung jawab untuk mewujudkan tata kelola yang baik serta pengendalian dan pengelolaan risiko yang efektif. Penelitian ini mengkonfirmasi teori stewardship dan teori peran dimana Inspektorat berperan sebagai organisasi pengawas yang dapat dipercaya untuk bertindak sesuai dengan kepentingan publik dengan melaksanakan tugas dan fungsinya. Dengan melaksanakan peran sebagai aparat pengawasan intern yang efektif maka akan mewujudkan peningkatan good governance. Penelitian ini mendukung hasil penelitian Yohanes, Paton dan Anwar (2016) bahwa Peran APIP yang efektif diharapkan menjamin penyelenggaraan urusan pemerintahan daerah dilaksanakan tertib, efisien dan efektif sesuai ketentuan perundang-undangan dan mendorong terwujudnya pemerintahan yang baik, bersih dan bebas KKN.

\section{Pengaruh Sistem Pengendalian Intern Pemerintah Terhadap Penerapan Good Governance}

Berdasarkan Tabel 4, nilai signifikansi variabel sistem pengendalian intern pemerintah adalah 0,035 lebih kecil dari nilai $\alpha=5 \%$ dan $\mathrm{t}_{\text {hitung }}=2,128>\mathrm{t}_{\text {tabel }}=1,978$. Hasil ini menunjukkan bahwa variabel peran APIP berpengaruh secara positif dan signifikan secara statistik terhadap variabel penerapan good governance pada tingkat keyakinan 95\%. Dengan demikian, hasil penelitian ini bahwa jika pimpinan dan seluruh pegawai berkomitmen dalam pelaksanaan SPIP secara optimal sesuai dengan ketentuan maka akan mendukung terwujudnya good governance di Kabupaten Kepulauan 
Talaud. Hal ini selaras dengan hipotesis yang dinyatakan dalam penelitian ini. Arens (2008) dalam Syamsir (2010) menyatakan bahwa sistem pengendalian intern adalah proses yang dirancang untuk menyediakan jaminan yang layak mengenai pencapaian dari sasaran manajemen pada kategori: (1) efektivitas dan efisiensi operasi; (2) keandalan dari laporan keuangan; (3) ketaatan terhadap hukum dan peraturan yang berlaku. Good governance dapat terlaksana karena sistem pengendalian intern pemerintah daerah sudah memadai. Hasil penelitian ini mendukung penelitian yang dilakukan oleh Sari (2013), Ristanti, Sinarwati, dan Sujana (2014), dan Armana (2016) dimana hasil penelitian menunjukkan bahwa sistem pengendalian intern berpengaruh positif dan signifikan terhadap penerapan good governance. Penelitian ini tidak mendukung hasil penelitian Ruspina (2013) yang meneliti pengaruh sistem pengendalian internal pemerintah (SPIP) terhadap penerapan good governance. Hasil pengujian menunjukkan bahwa Sistem Pengendalian Internal Pemerintah (SPIP) berpengaruh signifikan negatif terhadap penerapan good governance.

\section{Penutup}

\section{Kesimpulan}

Berdasarkan hasil uji hipotesis yang telah dilakukan, maka dapat disimpulkan bahwa:

1. Sistem akuntansi pemerintahan dipersepsikan oleh sejumlah responden berpengaruh positif dan signifikan secara statistik terhadap penerapan good governance. Hasil ini mengisyaratkan bahwa sistem akuntansi pemerintahan mampu mendorong penerapan good governance di Kabupaten Kepulauan Talaud.

2. Budaya organisasi berpengaruh negatif dan tidak signifikan secara statistik terhadap penerapan good governance di Kabupaten Kepulauan Talaud. Hasil ini tidak menunjukkan bahwa aparat pemerintah yang mematuhi budaya organisasi akan meningkatkan penerapan good governance. Hal ini terkait dengan karakteristik budaya aparatur pemerintahan yang disebabkan karena latar belakang umur, pendidikan, masa kerja, pengalaman kerja dan posisi jabatan yang berbeda dari setiap responden, sehingga persepsi budaya yang muncul adalah budaya individu pribadi dan tidak muncul budaya organisasi yang kuat dan dominan.

3. Kinerja aparatur pemerintah daerah berpengaruh positif dan signifikan secara statistik terhadap penerapan good governance. Hal ini menunjukkan bahwa jika aparatur sipil negara mampu menyelesaikan pekerjaan tepat waktu dengan hasil kerja yang rapih, minim kesalahan sesuai dengan sasaran kerja yang telah dibuat maka akan menghasilkan birokrasi yang handal dan profesional efisien, produktif serta memberikan pelayanan prima kepada masyarakat. Sehingga kinerja aparatur mendukung penerapan good governance di Kabupaten Kepulauan Talaud.

4. Peran APIP berpengaruh positif dan signifikan secara statistik terhadap penerapan good governance. Hal ini menunjukkan bahwa jika Inspektorat daerah melaksanakan fungsi dengan melakukan pengawasan melalui audit, reviu, evaluasi dan pemantauan dengan efektif serta menyampaikan laporan pengawasan tepat waktu maka akan mewujudkan tata kelola yang baik serta pengendalian dan pengelolaan risiko yang efektif. Sehingga Inspektorat daerah memiliki peran yang besar dalam upaya pencapaian good governance pada SKPD di Kabupaten Kepulauan Talaud.

5. Sistem pengendalian intern pemerintah berpengaruh positif dan signifikan secara statistik terhadap penerapan good governance. Hal ini menunjukkan bahwa jika pimpinan dan seluruh pegawai berkomitmen dalam pelaksanaan SPIP secara optimal sesuai dengan ketentuan maka akan mendukung terwujudnya good governance di Kabupaten Kepulauan Talaud.

\section{Saran}

Berdasarkan hasil penelitian ini, maka saran yang dapat diberikan adalah sebagai berikut.

1. Bagi pemerintah daerah, diharapkan dapat melaksanakan sistem akuntansi pemerintahan dengan baik melalui peningkatan sumber daya manusia pengelola keuangan, memperkuat budaya kerja melalui peningkatan motivasi dan perilaku untuk lebih mengutamakan orientasi pekerjaan pada pelayanan publik, memperkuat peran APIP dalam hal ini Inspektorat daerah terhadap akuntabilitas keuangan dan kinerja pemerintah melalui pendidikan dan pelatihan serta workshop dan pemberian insentif yang sesuai serta mengupayakan peningkatan kualitas dan kuantitas reward and punishment berdasarkan pencapaian kinerja pegawai.

2. Bagi praktisi, diharapkan penelitian ini dapat memberikan sumbangan pemikiran dalam mengambil kebijakan mengenai implementasi sistem akuntansi pemerintahan, budaya organisasi, kinerja 
aparatur pemerintah daerah, peran APIP, dan sistem pengendalian intern pemerintah agar good governance bisa tercapai;

3. Bagi akademisi, penelitian ini dapat memperkaya khasanah perkembangan ilmu pengetahuan di dunia pendidikan/akademis khususnya terkait dengan penerapan good governance, serta dapat menjadi bahan referensi terhadap masalah dan jenis penelitian yang sama.

\section{Daftar Pustaka}

Afiah, Nunuy Nur. 2010. Penerapan Prinsip-Prinsip Good Governmental Governance (Studi Empiris pada Faktor-Faktor: Kompetensi Aparatur, Kompetensi Anggota DPRD, Pelaksanaan Sistem Informasi Akuntansi, Penganggaran, dan Kualitas Informasi Keuangan). Jurnal Akuntansi Tahun XIV, No. 2, Mei 2010: 192-200.

Armana, Acang. 2016. Pengaruh Kinerja Satuan Pengawasan Internal terhadap Pelaksanaan Sistem Pengendalian Internal dan Penerapan Prinsip-Prinsip Good Corporate Governance (Suatu Study pada Organisasi Rumah Sakit). Tesis. Program Magister Manajemen. Fakultas Pasca Sarjana Universitas Pasundan, Bandung.

Bazar, Gani. 2011. Hambatan dalam Mewujudkan Good Governance. Artikel. (http://m/kompasiana.com/ganibazar). Diakses 18 Maret 2017.

Dodopo, Yoki, Jullie J. Sondakh dan Jantje Tinangon. 2017. Pengaruh Komitmen Organisasi, Pengendalian Intern Akuntansi, Peran Internal Audit, Pendidikan, dan Kualitas Pelatihan terhadap Keterandalan Laporan Keuangan pada SKPD Pemerintah Kabupaten Halmahera Utara. Jurnal Riset Akuntansi dan Auditing: Good Will. Vol.8, Buku 1: 22-31. Fakultas Ekonomi dan Bisnis. Universitas Sam Ratulangi Manado.

Enceng, Liestyodono B. I., dan Purwaningdyah, M. W. 2008. Meningkatkan Kompetensi Aparatur Pemerintah Daerah dalam Mewujudkan Good Governance. Jurnal Pusat Kebijakan dan Manajemen PNS, Volume 2, No. 1 juni 2008. Jakarta: Pusat Pengkajian dan Penelitian Kepegawaian BKN.

Fahmi, Irham. 2014. Perilaku Organisasi Teori, Aplikasi, dan Kasus. Bandung: Alfabeta.

Flippo B. E. 2000. Manajemen Personalia, Terjemahan. Jakarta: Erlangga.

Habibie. 2013. Pengaruh Pengawasan DPRD, Pengendalian Internal, dan Peran Auditor Internal terhadap Good Governance (Studi Empiris pada Pemerintah Kota Solok). Ejounal akuntansi Universitas Negeri Padang, Vol.1, No.1 (2013), seri H: 1-21.

Hanpuwadal, Nupakorn dan Ussahawanitchakit, Phapruke. 2010. Accounting Practice Effectiveness and Financial Performance of Thai Listed Firms: Mediating Effects of Decision Making Efficiency for Tax Management, Competent Resource Allocation, and Strategic Planning Success. European Journal of Management. Vol. 10, Issue 1.

Jermier, J. M., Slocum Jr., J.W, Fry, L.W., dan Gaines, J. 1991. Organizational Subculture in a Soft Bureaucracy: Resistance Behind the Myth and Facade of an Official Culture. Organization Science (Mei 1991). p:170-194.

Krina P., Loina Lalolo. 2003. Indikator dan Alat Ukur Prinsip Akuntabilitas, Transparansi dan Partisipasi. Jakarta: Sekretariat Good Public Governance Badan Perencanaan Pembangunan Nasional.

LAN dan BPKP. 2000. Akuntabilitas dan Good Governance. Jakarta: Lembaga Administrasi Negara.

Lenda, Siti Nurlily. 2013. Pengaruh Budaya Birokrasi terhadap Kinerja Aparatur di Sekretariat Daerah Kabupaten Bolaang Mongondow Utara. Journal Acta Diurna Vol. 2, No. 4 Tahun 2013.

Lestari, Morita Indah. 2013. Pengaruh Budaya Organisasi dan Pengendalian Intern terhadap Penerapan Prinsip-Prinsip Good Corporate Governance (Studi Empiris pada Rumah Sakit Umum di Kota Padang). Jurnal Akuntansi Vol. 1, No. 3.

Manossoh, Hendrik. 2015. Implementasi Sistem Akuntansi Pemerintahan dalam Mewujudkan Good Government Governance pada Pemerintah Provinsi Sulawesi Utara. Jurnal Berkala Ilmiah Efisiensi Vol. 15 No. 05 Tahun 2015. Manado: Fakultas Ekonomi dan Bisnis, Universitas Sam Ratulangi.

Mardiasmo. 2002. Elaborasi Reformasi Akuntansi Sektor Publik: Telaah Kritis terhadap Upaya Aktualisasi Kebutuhan Sistem Akuntansi Keuangan Pemerintah Daerah. Jurnal Akunting dan Auditing, Vol. 6 No.1, p:63-82. 2004. Otonomi dan Manajemen Keuangan Daerah. Yogyakarta: Penerbit Andi. 2009. Akuntansi Sektor Publik. Yogyakarta: Penerbit Andi. 
Mardiasmo, Diaswati, Barnes, Paul dan Sakurai, Yuka. 2008. Implementation of Good Governance by Regional Governments in Indonesia. The Twelfth Annual Conference of the International Research Society for Public Management (IRSPM XII), pages pp. 1-36. Brisbane, Australia.

Mathis, Robert L. dan Jackson, John H. 2006. Human Resource Management. Jakarta: Salemba Empat.

Osborne, David dan Gaebler. 1992. Reinventing Government: How the Entrepreneurial Spirit is Tranforming the Public Sector. New York: Penguins Book.

Pazri, Muhamad. 2016. Implementasi Prinsip Good Governance dalam Sistem Pengelolaan Keuangan Daerah di Indonesia. Badailama Law Journal, vol. 1 Issues 2, September 2016.

Republik Indonesia. 2013. Peraturan Menteri Dalam Negeri Nomor 64 Tahun 2013 tentang Penerapan Standar Akuntansi Pemerintahan Berbasis Akrual pada Pemerintah Daerah. . 2008. Peraturan Pemerintah Nomor 60 Tahun 2008 tentang Sistem Pengendalian Intern Pemerintah.

2010. Peraturan Pemerintah Nomor 71 Tahun 2010 tentang Standar Akuntansi Pemerintahan.

2003. Undang-Undang Nomor 17 Tahun 2003 tentang Keuangan Negara.

Ristanti, Ni Made Asih, Sinarwati, Nih Kadek, dan Sujana, Edy. 2014. Pengaruh Sistem Pengendalian Intern, Pengelolaan Keuangan Daerah dan Komitmen Organisasi terhadap Penerapan Good Governance (Studi Kasus pada Satuan Kerja Perangkat Daerah Kabupaten Tabanan). E-jurnal Program Akuntansi Universitas Pendidikan Ganesha, Volume 2, No. 1:2-14.

Robbins, P. Stephen, 1996. Perilaku Organisasi: Edisi Bahasa Indonesia Jilid I \& II. Jakarta: PT Prinhalindo.

Robbins, S.P. dan Judge, T.A. 2016. Perilaku Organisasi: Organizational Behavior. Jakarta: Salemba Empat.

Ruspina, Depi Oktia. 2013. Pengaruh Kinerja Aparatur Pemerintah Daerah, Pengelolaan Keuangan Daerah, Sistem Pengendalian Internal Pemerintah (SPIP) terhadap Penerapan Good Governance (Studi Empiris pada Pemerintah Kota Padang). Ejournal Universitas Negeri Padang, Jurnal Akuntansi, 1(3): 1-24

Sari, Diana. 2013. Pengaruh Sistem Pengendalian Intern Pemerintah, Implementasi Standar Akuntansi Pemerintahan, Penyelesaian Temuan Audit terhadap Penerapan Prinsip-Prinsip Tata Kelola Pemerintahan yang Baik (Penelitian pada Pemerintah Daerah di Provinsi Jawa Barat dan Banten). Simposium Nasional Akuntansi XVI Manado, 25-28 September. Universitas Widyatama Bandung. Sesi 1/10: 1007-1048.

Sari, Eka Nurmala. 2012. Pengaruh Budaya Organisasi terhadap Efektivitas Penerapan Akuntansi Sektor Publik serta Dampaknya terhadap Good Governance Studi pada Satuan Kerja Perangkat Daerah di Kota Medan. Jurnal Riset Akuntansi dan Bisnis vol 12 no.2 :25-54.

Sari, Maylia Pramono dan Raharja. 2012. Peran Audit Internal dalam Upaya Mewujudkan Good Corporate Governance (GCG) pada Badan Layanan Umum (BLU) di Indonesia. Simposium Nasional Akuntansi XV. Banjarmasin 20-23 September.

Sugiyono. 2014. Cara Mudah Menyusun Skripsi, Tesis dan Disertasi. Bandung: Penerbit Alfabeta.

Syamsir, Toni. 2014. Pengaruh Peran Inspektorat dan Budaya Organisasi Daerah terhadap Penerapan Good Governance (Studi Empiris Pada Pemerintah Kota Bukittinggi). Ejournal Universitas Negeri Padang. Jurnal Akuntansi, Vol.2 No. 3 (2014) Seri B: 1-21.

Tuasikal, Askam. 2009. Pengaruh Pengawasan, Pemahaman Sistem Akuntansi Keuangan dan Pengelolaan Keuangan terhadap Kinerja Unit Satuan Kerja Pemerintah Daerah (Studi pada Provinsi dan Kabupaten/Kota di Maluku). Jurnal Akuntansi, Vol.10, No.6 :66-88. Ambon: Universitas Pattimura.

Verasvera, Febrina Astria. 2016. Pengaruh Anggaran Berbasis Kinerja terhadap Kinerja Aparatur Pemerintah Daerah (Studi Kasus pada Dinas Sosial Provinsi Jawa Barat). Jurnal Manajemen, Vol.15, No.2, Mei 2016. Magister Manajemen Universitas Katolik Parahyangan.

Wakhyudi. 2010. Pemberdayaan Peran Audit Internal dalam Mewujudkan Good Governance pada Sektor Publik. Artikel. BPKP.

Wiratno, A., Pratiwi, U. dan Nurkhikmah. 2013. Pengaruh Budaya Organisasi, Gaya Kemimpinan, Komitmen Organisasi dan Pengendalian Intern terhadap Penerapan Good Governance serta Implikasinya pada Kinerja (Survey pada Kantor Pelayanan Perbendaharaan Negara Tegal). Proceeding Seminar Nasional \& Call For Papers (SCA-3). Universitas Jenderal Soedirman. Jurnal Vol. 3, No. 1 (2013) :1-8. 
Yohanes, E., Paton, A., dan Anwar A. 2016. Peran Aparat Pengawas Intern Pemerintah (APIP) dalam Penyelenggaraan Pemerintahan Daerah di Kabupaten Bulungan. EJournal Administrative Reform, 4(1):65-78 ISSN 2338-7637.

Yusniyar, Darwis dan Abdullah, S. 2016. Pengaruh Penerapan Sistem Akuntansi Pemerintahan dan Pengendalian Intern terhadap Good Governance dan Dampaknya pada Kualitas Laporan Keuangan (Studi pada SKPA Pemerintah Aceh). Jurnal Magister Akuntansi Pasca Sarjana Universitas Syiah Kuala, Banda Aceh. Vol. 5, No. $2: 100-115$.

Zeyn, Elvira. 2011. Pengaruh Penerapan Good Governance dan Standar Akuntansi Pemerintahan terhadap Akuntabilitas Keuangan. Jurnal Trikonomika Volume 10, No. 1,: 52-62. 